\title{
Thermal regime and dynamics of the West Antarctic ice sheet
}

\author{
Hermann ENGELHARDT \\ Division of Geological and Planetary Sciences, California Institute of Technology, Pasadena, CA 91125, USA \\ E-mail: hermann@skua.gps.caltech.edu
}

\begin{abstract}
The temperature-depth profiles measured in 22 boreholes drilled on the West Antarctic ice sheet exhibit two distinctly different thermal states of its basal ice. The warm state shows on Siple Dome and on Whillans Ice Stream. A relatively colder state, found at the Unicorn, Kamb Ice Stream (former Ice Stream C) and Bindschadler Ice Stream (former Ice Stream D), has basal temperature gradients greater than $50 \mathrm{~K} \mathrm{~km}^{-1}$. A large block of cold ice stranded and frozen to the bed at the Unicorn and simultaneously much warmer ice existing only a few kilometers across the Dragon shear margin in fastmoving Alley Ice Stream (former Ice Stream B2) poses a paradox. The relatively cold ice at the Unicorn must have come from a source different from the present Whillans Ice Stream catchment area. It is hypothesized that the Unicorn paradox was created by a super-surge. Also, the stagnant Siple Ice Stream, many relict shear margins, cold patches of ice at the Crary Ice Rise, ice rafts embedded in the Ross Ice Shelf, all point to a major event triggered either by an internal instability or by a subareal volcanic eruption. Most of these features appeared to have been formed about 500 years ago. Subsequent freeze-on of a 10-20 m thick basal layer of debris-laden ice and water loss caused a slowdown of ice streams and, in the case of Kamb Ice Stream, an almost complete stoppage.
\end{abstract}

\section{INTRODUCTION}

The West Antarctic ice sheet (WAIS) is vitally controlled by processes at its base (Kamb, 2001). The fast-moving ice streams within the WAIS are moving at speeds 10-100 times greater than the surrounding ice sheet, with the exception of Kamb Ice Stream that slowed about 150 years ago but had been very active before that, judging from the buried crevasses (Retzlaff and Bentley, 1993). These ice-stream speeds are much faster than those that can be explained by internal deformation of the ice alone. Additional mechanisms have been invoked to account for this remarkable dynamics. Before basal sliding processes become active, the bed must be at the melting point (Engelhardt and Kamb, 1998). Therefore, thermal conditions under and in the ice are of primary importance for ice streaming to occur. Temperature measurements not only reflect present conditions at the bed, but also contain the thermal history within the ice that in many cases is far from a steady-state temperature distribution (Jenssen and Radok, 1961; Radok and others, 1970, Engelhardt, 2004).

\section{TEMPERATURE MEASUREMENTS}

The present paper summarizes the results of all temperaturedepth profile measurements in 22 out of 119 boreholes drilled through the ice with the hot-water drilling technique during the field seasons 1988-2001. The boreholes were located on Whillans Ice Stream (WIS), Kamb Ice Stream (KIS; former Ice Stream C), and Bindschadler Ice Stream (BIS; former Ice Stream D), on Engelhardt Ridge (ER; former ice ridge $\mathrm{BC}$ ), on Raymond Ridge (RR; former ice ridge $C D$ ), on the Unicorn (UC) between Van der Veen Ice Stream (VIS; former Ice Stream B1) and Alley Ice Stream (AIS; former Ice Stream B2), on a former shear margin within the Unicorn, called the Fishhook, and in the Dragon, the southern shear margin of AIS with the Unicorn (Fig. 1). Because the boreholes occur in clusters at the drilling sites, they are not individually resolved in the figure.
The temperature sensors were thermistors, which were carefully calibrated for the expected temperature range to $\pm 0.02^{\circ} \mathrm{C}$. They were protected from pressure in small metal cases with electrical feed-through. They were emplaced vertically $100 \mathrm{~m}$ apart in the freshly drilled and therefore water-filled boreholes. In the lowest and highest 100-200 m of the borehole the spacing of the thermistors was $20 \mathrm{~m}$. The thermistors froze in within $<1$ day in the upper half of the borehole, but required more time in the warmer, lower part of the borehole, and up to several weeks $20 \mathrm{~m}$ above the bed. The temperatures were measured daily and again

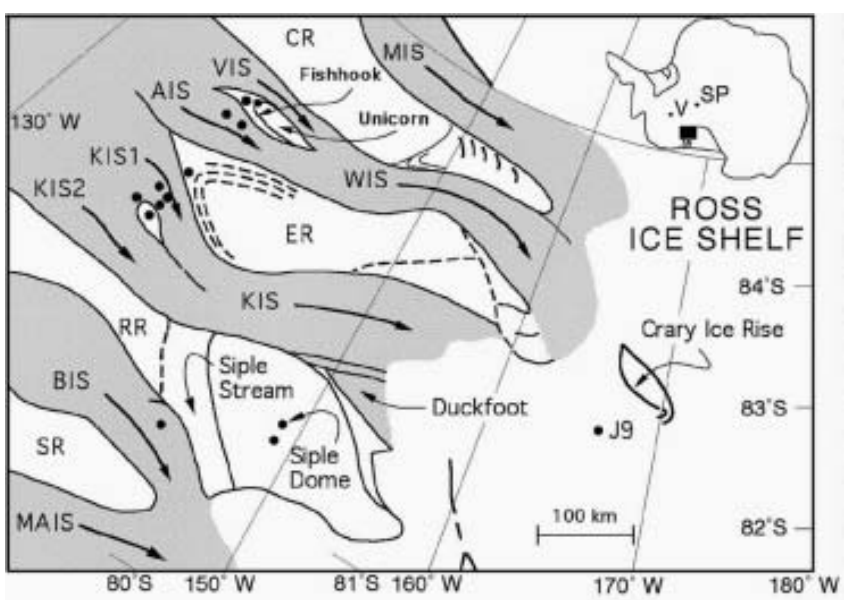

Fig. 1. Study area of the WAIS. Drill sites are indicated as black dots that in most cases represent more than one borehole. The locations of all the boreholes are listed in Table 1. South Pole (SP) and the position of a volcano $(\mathrm{V})$ are also indicated. The new names of ice streams and interstream ridges are abbreviated: MIS, Mercer Ice Stream; WIS, Whillans Ice Stream; VIS, Van der Veen Ice Stream; AIS, Alley Ice Stream; KIS, Kamb Ice Stream; BIS, Bindschadler Ice Stream; MAIS, MacAyeal Ice Stream; CR, Conway Ice Ridge; ER, Engelhardt Ice Ridge; RR, Raymond Ice Ridge; SR, Shabtaie Ice Ridge. 
Table 1. Temperatures measured in boreholes

\begin{tabular}{|c|c|c|c|c|c|c|}
\hline Borehole site & Location & $\begin{array}{l}\text { Ice thickness } \\
\qquad \mathrm{m}\end{array}$ & $\begin{array}{l}\text { Surface velocity } \\
\qquad \mathrm{m} \mathrm{a}^{-1}\end{array}$ & $\begin{array}{c}\text { Surface } \\
\text { temperature } \\
{ }^{\circ} \mathrm{C}\end{array}$ & $\begin{array}{c}\text { Bed } \\
\text { temperature } \\
{ }^{\circ} \mathrm{C}\end{array}$ & $\begin{array}{c}\text { Basal temperature } \\
\text { gradient } \\
\mathrm{K} \mathrm{km}^{-1}\end{array}$ \\
\hline \multicolumn{7}{|l|}{ Warm ice } \\
\hline WIS $88-1$ & $83^{\circ} 29^{\prime} 58^{\prime \prime} \mathrm{S}, 138^{\circ} 25^{\prime} 26^{\prime \prime} \mathrm{W}$ & 1035.0 & 443.0 & -25.20 & -0.71 & -37.0 \\
\hline WIS $89-3,4$ & $83^{\circ} 29^{\prime} 10^{\prime \prime} S, 138^{\circ} 31^{\prime} 15^{\prime \prime} \mathrm{W}$ & 1057.0 & 443.0 & -25.20 & -0.70 & -37.0 \\
\hline WIS 91-1 & $83^{\circ} 29^{\prime} 00^{\prime \prime} \mathrm{S}, 138^{\circ} 25^{\prime} 36^{\prime \prime} \mathrm{W}$ & 1055.0 & 438.0 & -25.25 & -0.81 & -44.0 \\
\hline WIS 92-2,6 & $83^{\circ} 29^{\prime} 05^{\prime \prime} \mathrm{S}, 138^{\circ} 27^{\prime} 29^{\prime \prime} \mathrm{W}$ & 1052.0 & 424.0 & -25.21 & -0.70 & -42.0 \\
\hline WIS $95-4,7$ & $83^{\circ} 27^{\prime} 43^{\prime \prime} S, 138^{\circ} 56^{\prime} 47^{\prime \prime} \mathrm{W}$ & 1026.3 & & -24.94 & -0.75 & -49.6 \\
\hline ER 96-12 & $82^{\circ} 40^{\prime} 36^{\prime \prime} \mathrm{S}, 135^{\circ} 49^{\prime} 31^{\prime \prime} \mathrm{W}$ & 1123.9 & 10.9 & -25.85 & -1.11 & -43.3 \\
\hline SD 97-1 & $81^{\circ} 39^{\prime} 30^{\prime \prime} \mathrm{S}, 148^{\circ} 48^{\prime} 30^{\prime \prime} \mathrm{W}$ & 1004.6 & 0.0 & -24.55 & -2.54 & -32.7 \\
\hline RR 97-42 & $81^{\circ} 35^{\prime} 47^{\prime \prime} S, 148^{\circ} 41^{\prime} 38^{\prime \prime} W$ & 955.0 & & -24.55 & & \\
\hline Byrd* & $80^{\circ} 00^{\prime} 01^{\prime \prime} \mathrm{S}, 119^{\circ} 31^{\prime} 00^{\prime \prime} \mathrm{W}$ & 2164.0 & $13.0^{* *}$ & -28.5 & -1.7 & -32.5 \\
\hline $\mathrm{CIR}^{* * *}$ & $83^{\circ} 02^{\prime} 22^{\prime \prime} \mathrm{S}, 172^{\circ} 56^{\prime} 51^{\prime \prime} \mathrm{W}$ & 480.0 & $<5.0$ & -24.5 & -5.7 & 45.2 \\
\hline \multicolumn{7}{|l|}{ Cold ice } \\
\hline UC 93-9 & $83^{\circ} 34^{\prime} 24^{\prime \prime} \mathrm{S}, 138^{\circ} 08^{\prime} 58^{\prime \prime} \mathrm{W}$ & 908.4 & 2.8 & -25.09 & -1.38 & -83.5 \\
\hline UC 93-11 & $83^{\circ} 34^{\prime} 46^{\prime \prime} \mathrm{S}, 138^{\circ} 08^{\prime} 45^{\prime \prime} \mathrm{W}$ & 910.6 & 2.0 & -25.09 & -2.48 & -81.0 \\
\hline UC 93-14 & $83^{\circ} 40^{\prime} 45^{\prime \prime} S, 138^{\circ} 22^{\prime} 18^{\prime \prime} \mathrm{W}$ & 1091.6 & 1.6 & -25.09 & -3.43 & -51.5 \\
\hline UC 93-16 & $83^{\circ} 36^{\prime} 39^{\prime \prime} \mathrm{S}, 138^{\circ} 02^{\prime} 31^{\prime \prime} \mathrm{W}$ & 962.3 & 0.5 & -25.09 & -1.28 & \\
\hline KIS 96-2 & $82^{\circ} 26^{\prime} 42^{\prime \prime} \mathrm{S}, 135^{\circ} 58^{\prime} 36^{\prime \prime} \mathrm{W}$ & 1189.0 & 14.0 & -26.92 & -1.13 & -54.6 \\
\hline KIS $00-1,2$ & $82^{\circ} 22^{\prime} 00^{\prime \prime} \mathrm{S}, 136^{\circ} 24^{\prime} 00^{\prime \prime} \mathrm{W}$ & 949.4 & 3.0 & -25.50 & -1.38 & -60.5 \\
\hline KIS 00-6 & $82^{\circ} 25^{\prime} 57^{\prime \prime} \mathrm{S}, 136^{\circ} 24^{\prime} 08^{\prime \prime} \mathrm{W}$ & 1191.8 & 12.0 & -25.50 & -1.21 & -63.4 \\
\hline KIS 00-9 & $82^{\circ} 23^{\prime} 59^{\prime \prime} \mathrm{S}, 136^{\circ} 24^{\prime} 16^{\prime \prime} \mathrm{W}$ & 1033.5 & 6.0 & -25.50 & -0.81 & -71.3 \\
\hline BIS 98-4,5 & $81^{\circ} 04^{\prime} 25^{\prime \prime} \mathrm{S} 140^{\circ} 00^{\prime} 19^{\prime \prime} \mathrm{W}$ & 1086.0 & 365.0 & -24.35 & -0.82 & -61.2 \\
\hline $\mathrm{CIR}^{* * *}$ & $83^{\circ} 15^{\prime} 00^{\prime \prime}$ S $172^{\circ} 37^{\prime} 54^{\prime \prime} \mathrm{W}$ & 369.0 & $<5.0$ & -25.0 & -3.8 & 70.0 \\
\hline
\end{tabular}

Notes: WIS, Whillans Ice Stream; KIS, Kamb Ice Stream; BIS, Bindschadler Ice Stream; ER, Engelhardt Ice Ridge; RR, Raymond Ice Ridge; SD, Siple Dome; UC, Unicorn; CIR, Crary Ice Rise. The borehole site entries contain the year of drilling season followed by the number of the borehole. *Gow and others (1968). ** Bindschadler and others (1996). *** Bindschadler and others (1990).

1-4 years later, when the borehole sites were revisited to collect the data loggers. From selected borehole sites we had Argos satellite data transmission. In general, temperature profiles accurate to $0.05 \mathrm{~K}$ required equilibration periods of about 1 year. Details of the procedure are given in Engelhardt and Kamb (1993).

\section{OBSERVATIONS}

The whole study area is low in elevation, 300-600 ma.s.l. The ice is relatively thin, 900-1200 m, and has a very low

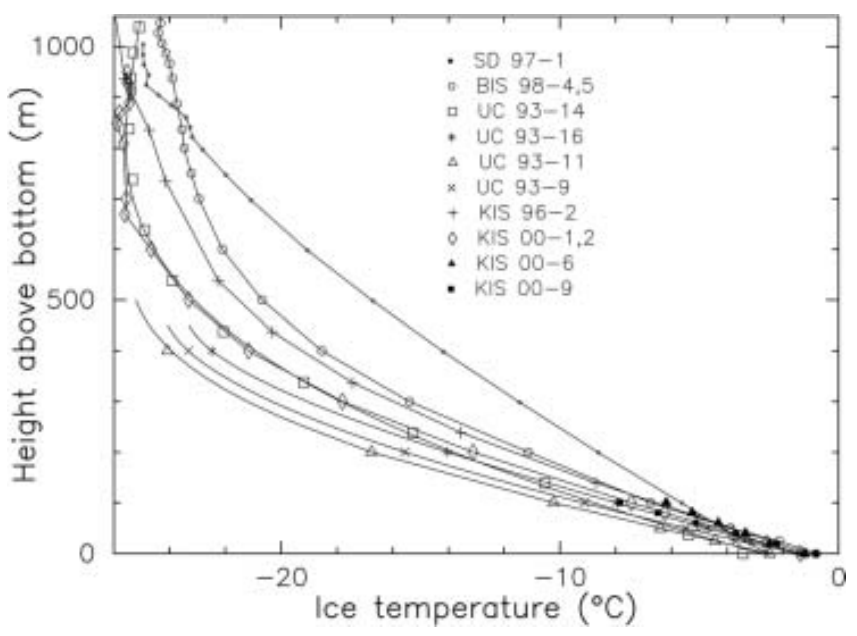

Fig. 2. Temperature-depth profiles of sites significantly colder than the Siple Dome temperature profile in borehole SD 97-1. High basal temperature gradients. surface slope of 0.001 . The surface temperatures are between -25 and $-27^{\circ} \mathrm{C}$ (Table 1). Since bed temperatures are at or near the pressure-melting point, the differences between top and bottom temperatures lie between 21.7 and $25.8^{\circ} \mathrm{C}$. All fast-moving ice streams are wet at the base. The basal temperatures are sometimes a few tenths of a degree below the pressure-melting point for a pure ice/water interface, due to the impurity content of the ice and of the water at the ice/till interface (Wettlaufer, 1999a). Kamb Ice Stream, a special case that stopped rapid motion about 150 years ago (Whillans and others, 2001), still has a melted bed except for a sticky spot around boreholes KIS 00-1,2 (Table 1) and KIS 00-3, another borehole drilled in the same area, which revealed a frozen bed from the drilling record and borehole images. Interstream ridges, like RR between KIS and BIS, and the Unicorn between VIS and AIS, are frozen to the bed.

\section{BASAL TEMPERATURE GRADIENTS}

Despite similar depths and surface temperatures of the boreholes within our study area, there is one very obvious difference. The basal temperature gradients (Table 1) were determined from a linear fit through the measurements in the lowest $100 \mathrm{~m}$. They fall into two distinct groups, those with a temperature gradient higher than, and those with a gradient lower than, $50 \mathrm{~K} \mathrm{~km}^{-1}$. The ice in the basal zone with the higher or stronger temperature gradients is colder than the ice in the lower or weaker temperature gradient group, which is warmer relative to the other group. Therefore, we call one group the cold-ice group (Fig. 2), the other the warm-ice group (Fig. 3). The Siple Dome profile, a typical 


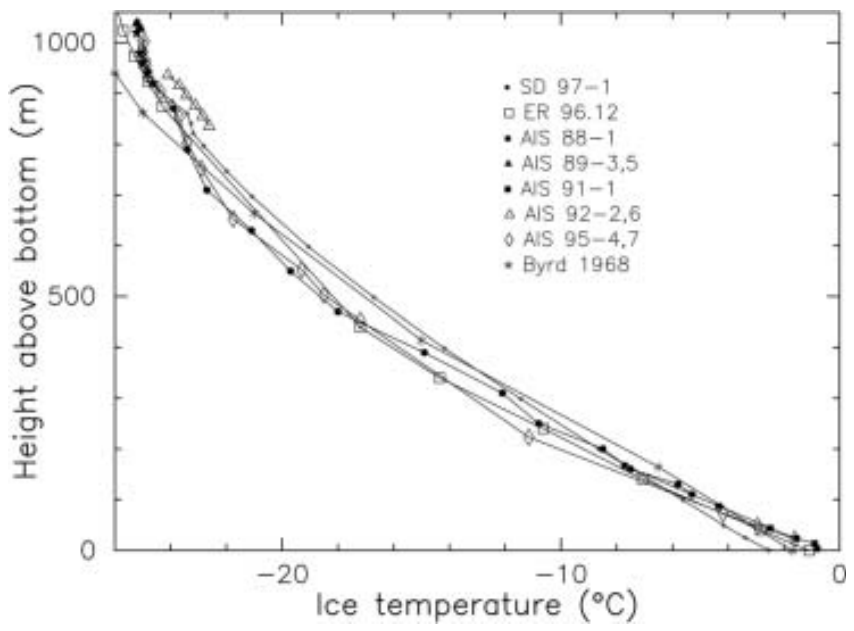

Fig. 3. Temperature-depth profiles of Whillans Ice Stream, Siple Dome, and Byrd (Gow and others, 1968). Low basal temperature gradients.

temperature profile falling into the warm group, is included in Figure 2 for comparison. In Table 1, the temperature profiles in the Byrd and Crary Ice Rise boreholes are also cited for comparison.

Siple Dome (SD) is the best example of ice that has been frozen to the bed for at least $100 \mathrm{kyr}$ (Nereson and others, 1996), but, because of the temperature changes that occurred $10 \mathrm{kyr}$ ago after the last glacial period, its temperature profile has not reached full steady state (Engelhardt, 2004). Because of its unique location at a stable dome site, the SD temperature profile had more time to approach steady state than all the other measurement sites that experienced continuous changes in boundary conditions due to flow. The temperatures in boreholes of WIS and of ER are not too much different from the SD profile. The Byrd borehole basal temperature gradient is also similar to the SD case.

All other boreholes on KIS and BIS and on the Unicorn (UC), a stagnant island between VIS and AIS, with basal temperature gradients sometimes much higher than $50 \mathrm{~K} \mathrm{~km}^{-1}$, seem to be far from steady state. One borehole, UC 93-14, also called the Fishhook borehole, was drilled at a location of the old, now inactive shear margin, the Fishhook within the UC. The ER borehole, ER 96-12, is also relatively close to or on an old shear margin with KIS.

Steady state is approached if boundary conditions are kept stable for a long time. Given the boundary conditions, surface temperature, accumulation rate, bed temperature, and using the material properties of ice, its thermal conductivity, one can calculate theoretical steady-state temperature profiles (Radok and others, 1970). If we compare the measured temperature profiles that have similar boundary conditions with the theoretical profiles, one should see that those with warmer ice temperatures are closer to steady state than the ones with colder temperatures relative to the others. For example, compare the SD temperature profile with the UC profiles, which are located not far apart on the WAIS. Surface and bed temperatures are very close, both are frozen to the bed, accumulation rate should be similar, and thickness is comparable: $1000 \mathrm{~m}$ at SD and 900-1100 $\mathrm{m}$ at the UC. One would expect similar temperatures, especially similar basal temperature gradients; but no, the temperature profiles are distinctly different. One

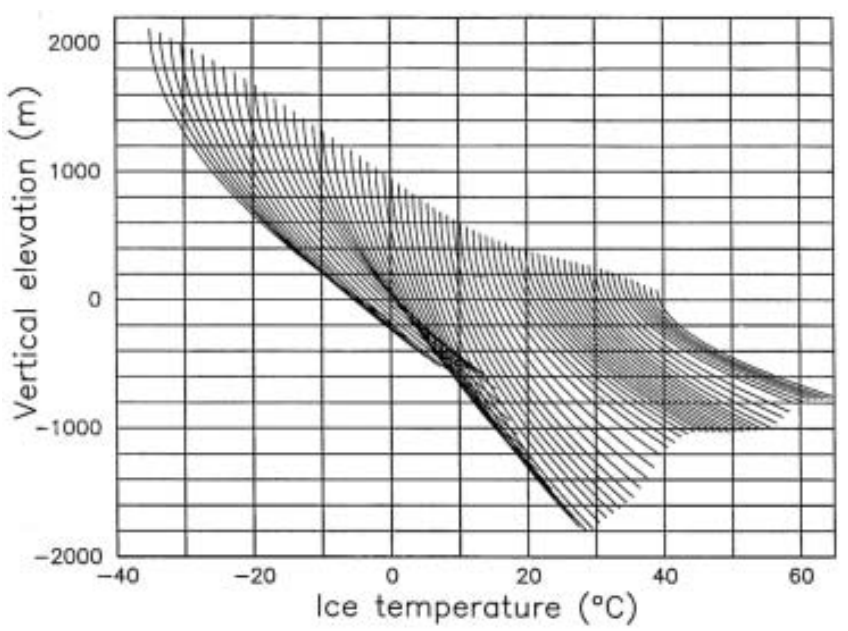

Fig. 4. Temperature profiles along flowline from ice divide to grounding line every $10 \mathrm{~km}$. Each of the 67 profiles is offset by one degree with respect to the previous one. The first profile at the ice divide (left) shows the actual temperatures.

could produce steeper temperature profiles by drastically changing the boundary conditions, for instance by increasing the accumulation rate by a factor of two or reducing the surface temperature by $10^{\circ} \mathrm{C}$. This is unrealistic and would be rejected as questionable. So there is what might be called a dilemma, a paradox, a discrepancy. One possible explanation of this phenomenon is presented here as a working hypothesis, admittedly still speculative because of the complex nature of the events.

\section{THE UNICORN PARADOX}

The Unicorn temperature profiles reveal a high basal temperature gradient indicating relatively cold ice near the bed. But, just a few kilometers across the Dragon shear margin to the north on AIS, the temperature gradient is much lower and the ice is distinctly warmer. These observational facts reproduced in many boreholes on both sides of the Dragon are a paradox that requires a satisfactory explanation.

High basal temperature gradients can arise from two effects: first, from basal melting caused by high geothermal flux, and secondly, from substantial longitudinal extensional flow.

The UC is frozen to the bed, which excludes a local geothermal flux that is high enough for melting the ice at the bed. The UC ice velocities are very low, with no extensional flow to produce changes in the temperature profile. Since the boundary conditions of the UC and SD are similar, we would expect that the temperature profiles of the UC should be similar to that of SD. However, they are markedly different. Therefore, UC ice cannot have formed locally, it must have come from somewhere else.

The nearest candidate for supplying ice to the UC would be WIS and its tributaries AIS and VIS. But although WIS has a wide catchment area and an overdeepened interior and is also flowing fast, extensional flow did not produce any appreciable cooling of the basal ice. Instead, the measured profiles show much warmer ice than those in the UC, which is consistent with the modeling of the temperature evolution (Fig. 4; Lingle and Brown, 1987; Engelhardt and Kamb, 1993). The basal temperature gradient changes from $24.3 \mathrm{~K} \mathrm{~km}^{-1}$ at the ice divide to $49.1 \mathrm{~K} \mathrm{~km}^{-1}$ at the grounding 


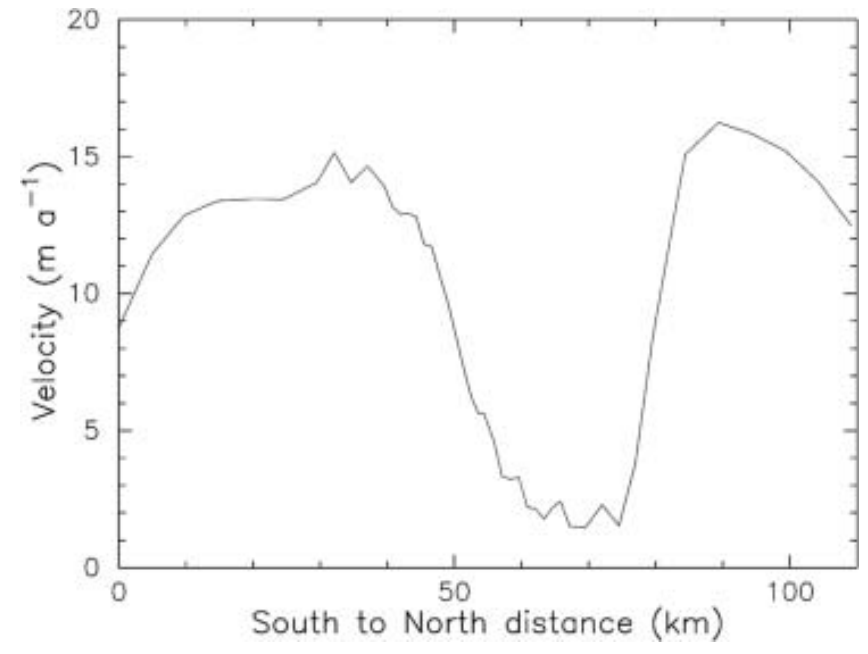

Fig. 5. Velocity profile across Kamb Ice Stream, including the sticky spot.

line. Therefore it is almost impossible to have the UC ice with a gradient of $83.5 \mathrm{~K} \mathrm{~km}^{-1}$ originate from the WIS system unless very implausible assumptions are made about the recent evolution of its basal conditions. WIS could not possibly have delivered cold ice only several hundred years ago and have been heated up since then to achieve the present temperature profile. Since UC ice could not have formed locally and could not have been supplied by WIS, we have to find yet another source. In the following we will try to test the hypothesis that the UC ice comes from KIS, the next nearest source.

At first it seems far-fetched to assume that cold ice had to cross WIS to be delivered to the UC where at some point it was left stranded and began to freeze to the bed.

Both the temperature profiles of the UC and KIS are strikingly similar, so that there is no problem in making the thermal connection. However, to overcome the barrier of WIS or AIS, the critical assumption has to be made that KIS had to be in a state of extremely vigorous flow, in a state of surge of such magnitude that we call it a super-surge. A dramatic event of this type may be necessary to explain the UC paradox. Surges of course are well known. They can be initiated in a fairly short period of time. In Alaska, USA, surges start within weeks or months, with speed-ups over a limited time by a factor of up to 100, and they terminate in hours or days, as was the case with Variegated Glacier (Kamb and others, 1985). The super-surge must have had enough force to overwhelm and push away slower-moving WIS and deposit colder ice at the UC. In surge situations, one can often observe highly convoluted medial moraines and cut-off or displacement of non-surging tributaries. After the supersurge stopped, normal flow of WIS resumed, fed from a catchment area like the one used today. The stranded, cold UC ice started freezing to the bed. This relatively young basal ice at the $U C$ is still far from a steady state as compared to SD. It will require thousands of years to approach equilibrium.

Surges are episodes of vigorous flow that are far out of balance. They can last only a limited time because they exhaust their source area to a point where flow is no longer sustainable. Most surges are triggered by internal instabilities or critical thresholds where basal temperatures, water storage and water pressure play a crucial role to create a slippery bed. Since the WAIS is in a rift zone, elevated geothermal flux can be expected, which in fact has been measured at Siple Dome to be $69 \mathrm{~mW} \mathrm{~m}^{-2}$ (Engelhardt, 2004), and which is shown on a heat-flow map of Antarctica created by Ritzwoller and others (2001) using the global heat-flow database and guided by a 3-D velocity model of the crust and upper mantle. The average geothermal flux of West Antarctica is $100 \mathrm{~mW} \mathrm{~m}^{-2}$, three times higher than that of East Antarctica. Geothermal flux in rift zones can be quite variable, even much higher than that at SD. In places where the ice is deep enough, melting will eventually occur. The $2164 \mathrm{~m}$ deep Byrd borehole is melted at the bed. However, the Byrd borehole has a basal temperature gradient similar to that of SD, suggesting a geothermal flux similar to that of $\mathrm{SD}$. The basal ice is warm in contrast to KIS.

After being vigorously active for a limited time, KIS stopped almost completely in the lower part to a speed of presently $0-20 \mathrm{ma}^{-1}$, while in the upper reaches it is still moving at a modest speed of $60 \mathrm{~m} \mathrm{a}^{-1}$ (Fig. 5; Conway and others, 2002). During the surge the surface of KIS was heavily crevassed, which was observed by radar sounding in numerous transects. In one case we realized we were drilling into a large crevasse buried about $30 \mathrm{~m}$ deep below surface, because we could freely lower the drill an additional $30 \mathrm{~m}$ into a void. After the surge stoppage, layers of undisturbed firn buried the crevasses. From the total thickness of the undisturbed layers and the accumulation rate, the time of stoppage about 150 years ago was obtained (Retzlaff and Bentley, 1993). Several areas of deeper buried crevasses and shear margins near SD have also been recognized (Jacobel and others, 2000; Nereson, 2000). The most prominent one is situated north of RR, named the 'Siple Ice Stream'. The buried features point to an event that peaked and then declined about 500 years ago. This is evidence that 500 years ago the WAIS system was considerably more active than it is now.

As shown for WIS (Fig. 4), longitudinal extension does not contribute enough to produce a steep basal temperature gradient as found in KIS. In fact, internal strain heating may even counterbalance the extensional effect. Jacobshavn Isbræ, Greenland, for example shows a $400 \mathrm{~m}$ thick layer of temperate basal ice (Iken and others, 1993). But during a very active surge phase, cooling from very high extensional flow may play a role. Another way to achieve a steep basal temperature gradient as in KIS is substantial basal melting. This could occur in the deepest part of KIS where one arm flows out of the Bentley Trench. Extensive modeling of KIS shows the relative contributions of basal melting and extensional flow (Vogel and others, 2003). Another possibility that cannot be ruled out completely is the existence of an active subglacial volcano that was reported by Blankenship and others (1993) using aero-geophysical data. This volcano, if confirmed by additional surface measurements and borehole drilling, would be located at the right spot in the upper catchment area of KIS at $81.8767^{\circ} \mathrm{S}, 111.3017^{\circ} \mathrm{W}$ (Fig. 1). Tulaczyk and others (1998) discovered about 3\% volcanic material in till samples of the ice streams, a small but not negligible amount. This would be consistent with a relatively recent eruption, so that erosion of volcanic rock and mixing into the till has not yet significantly altered the till composition. If this volcano existed and erupted more than 500 years ago, it could have caused substantial basal melting, which in turn could have triggered the super-surge that peaked about 500 years ago, leaving behind a number of features that are still vividly displayed by the temperature 
profiles, the buried crevasses and shear margins, and distorted flowlines on the Ross Ice Shelf.

The amount of melting that would be needed to arrive at present KIS temperature profiles can be estimated by starting with a WIS-type temperature profile. Full transition from WIS to KIS temperatures within the last 500 years, from melting alone, would require the removal of about $200 \mathrm{~m}$ of basal ice. This demonstrates the severity of the difference between the two types of temperature profiles. In any case, a great amount of water is necessary to keep the ice streams lubricated, especially the cold ones. Without additional water supplied from upstream sources, KIS and BIS would eventually freeze into their beds and stop moving completely. KIS has already done so in part. Cooling from extensional flow alone is not sufficient. It must be a combination of both melting and extensional flow.

In favor of the volcano hypothesis is the creation of a huge meltwater reservoir with no pre-existing drainage system. A surge normally starts from an area that becomes critically unstable when the ice is uncoupled from the bed by high water pressure. Once started, a surge bulge propagates mostly downslope at relatively high speeds, activating the ice in its path. It also can activate additional upstream areas. Under surge conditions, water flows under the ice in a sheet, because water channels are unstable and are destroyed. Behind the surge front, basal water at high pressure is retained, providing efficient lubrication for the surge. When the surge front reaches the terminus, in our case the grounding line, an outburst flood will terminate or slow down the surge considerably.

The UC paradox and many features in the Siple Coast icestream system can be explained under such a scenario (Scambos and others, 1998; Fahnestock and others, 2000; Jacobel and others, 2000). With a typical ice stream length of about $600 \mathrm{~km}$ and a typical surge speed of $10-100 \mathrm{~m} \mathrm{~d}^{-1}$, and the surge front passing at a speed of the same order of magnitude, normally higher, the super-surge episode would have lasted somewhere between 16 and 160 years. A supersurge would also have delivered a huge amount of additional ice to the Ross Ice Shelf, which would translate into increased calving at the ice-shelf front. The curves of relative sea-level rise over the last 2000 years show conspicuous spikes 600-400years ago even during the Little Ice Age (Nydick and others, 1995).

The super-surge obliterated the normally smooth flowlines between the ice streams' grounding line and the iceshelf front. By comparison, the flowlines on the Ronne Ice Shelf are well preserved, not altered by interference of a drastic event. The surface features on the Ross Ice Shelf are a jumble of ice rafts, irregular crevasse patterns, old flowlines at an angle to present flow directions, and highly distorted flowlines (Casassa and Turner, 1991), and kinks in surface slope (Gray and others, 2002).

\section{KAMB ICE STREAM}

KIS was probably the most active player under the supersurge scenario. Its position in the middle of the surge fan down-glacier from the source region of meltwater provided ample lubrication. An outburst flood at the grounding line, a common feature of fast glacier surges, must have drained enough water for the ice stream to become less lubricated. It settled down and essentially came to a halt. KIS contains cold ice with a high basal temperature gradient of -60 to
$-70 \mathrm{~K} \mathrm{~km}^{-1}$. There is still enough water at the bed of the ice stream, so that freeze-on of ice, sometimes mixed with till, continues. Drainage now occurs in a more channeled fashion. One of our boreholes, KIS 00-9, entered into a water-filled cavity that was $1.4 \mathrm{~m}$ deep. The water pressure in this channel is almost 1 bar below the ice overburden pressure. Therefore, the drainage through these channels must be well developed, unlike in fast-moving ice streams where basal water pressure is much closer to the flotation level and drainage must be in a thin sheet (Engelhardt and Kamb, 1997). Judging from the lowest frozen-on debris-free ice layer, there must be a channel at least $200 \mathrm{~m}$ long where the ice did not touch the till bed. Presently, freeze-on is $7 \mathrm{~mm} \mathrm{a}^{-1}$, which we calculated from the basal temperature gradient of $-60 \mathrm{~K} \mathrm{~km}^{-1}$, the heat conductivity of ice and the geothermal flux of $69 \mathrm{~mW} \mathrm{~m}^{-2}$ measured at nearby SD. The total freeze-on after the initial volcanic melt event is $10 \mathrm{~m}$, of which $7 \mathrm{~m}$ is clear ice with very little debris content. The topmost layer with debris is located about $1 \mathrm{~m}$ below the bubbly-ice to clear-ice transition. The lowest $5 \mathrm{~m}$ is a complex sequence of debris-laden layers alternating with clear ice layers. At the present freeze-on rate of $7 \mathrm{~mm} \mathrm{a}^{-1}$, the total freeze-on of basal ice would require 1450 years. The initial freeze-on rate after the melting phase must have been much higher because of the initially higher temperature gradient. The time since freeze-on started is probably much less than 1450 years. Other ways of debris entrainment and other freeze-on processes such as diffusion of water along grain boundaries may have contributed at various times (Wettlaufer, 1999b). Basal water flow under depressurizing conditions along a hydraulic gradient will form frazil ice that can accrete at the base because of the Clausius-Clapeyron effect.

In the middle of KIS is a bedrock hump about $100 \mathrm{~m}$ higher in elevation than the surrounding ice-stream bed. This hump was overrun by the super-surge because it has the same temperature profile as KIS, but it was also a place where freeze-on occurred first, creating a sticky spot. The cold ice got stranded there, while the still active ice had to flow around it, forming the present flow stripes. The sticky spot is a drop-shaped feature $15 \mathrm{~km}$ across and $30 \mathrm{~km}$ long. It could be seen as an analog to the UC. Figure 5 shows the velocity profile across KIS, including the sticky spot. Although the basal temperature there is only $-1.38^{\circ} \mathrm{C}$, the bed is solidly frozen. In three boreholes drilled through the KIS sticky spot, a connection with a basal water system could not be established. One borehole, KIS 00-10, in the transition zone between the sticky spot and KIS, exhibited a delayed connection to the basal hydraulic system, showing that the ice is barely frozen or starting to freeze to the bed. A similar weak connection was also found in borehole ER 9612 at the southern margin of KIS.

All the other boreholes drilled on KIS made instant connection to the basal hydraulic system, allowing water to flow out of the borehole, as indicated by a water-level drop in the borehole from $30 \mathrm{~m}$ to about $100 \mathrm{~m}$ below the surface. The best connection was made in borehole KIS 00-9, which intersected a subglacial channel with water flowing at a speed of several centimeters per second.

Therefore, KIS outside the sticky spot is presently not frozen to its bed. However, freeze-on of basal ice and debris is still going on because there is enough water available in the till and resupplied by still active channels from reservoirs upstream. Overall, this ongoing freeze-on process has 


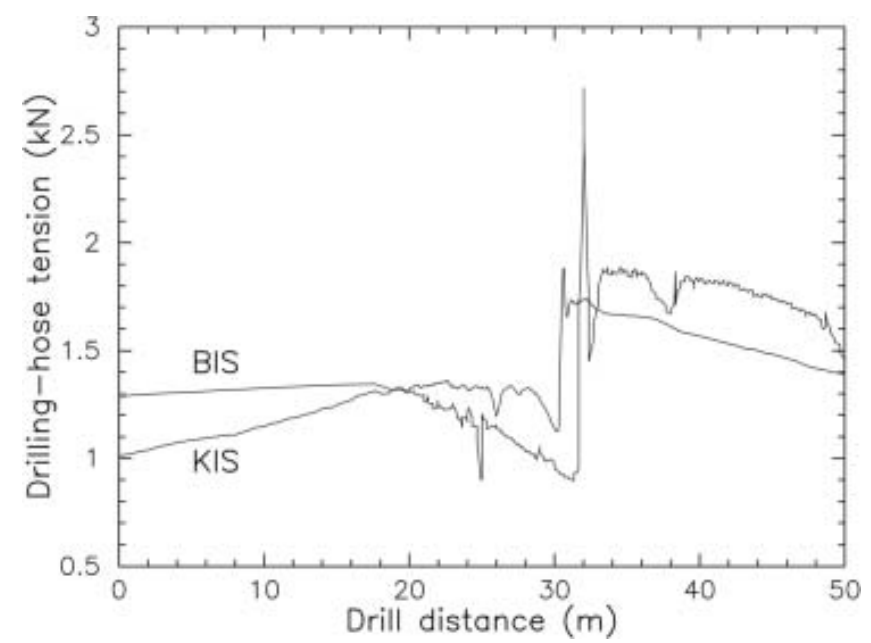

Fig. 6. Drilling-hose tension indicating a basal debris-laden ice layer under Kamb and Bindschadler Ice Streams. The sharp peaks are caused by water-level drop in the boreholes when the drill reaches the bed and the borehole connects to a basal hydraulic system.

reduced basal lubrication and increased basal friction. Other features, like the Duckfoot, were active during the super-surge as well. Stranded shear margins are still visible as topographic surface features and as disturbed subsurface layering detected by radar (Jacobel and others, 2000). The slow-down of KIS is a consequence of water loss, basal freeze-on and formation of sticky spots.

\section{WHILLANS ICE STREAM}

A branch of the super-surge has very likely invaded the WIS area. This fast-moving ice must have spilled over and temporarily replaced the normal flow of ice from the WIS catchment area. The cold ice also overran the Unicorn area except for a small island below the Fishhook, which is still visible as a prominent feature within the UC (Clarke and others, 2000). As the surge subsided, a mass of relatively cold ice was left stranded on the UC, now a frozen bed island between VIS and AIS. Subsequently, the ice flowing from the WIS catchment area returned to its previous flow regime, pushing the cold ice downstream. Therefore, the temperatures in this part of WIS are again warmer and no longer affected by super-surge generated ice, and the freeze-on rate is practically zero. If this interpretation is correct, then a large body of colder ice still exists in the lower reaches of WIS and on the Ross Ice Shelf. The presence of cold ice in the downstream WIS area can also explain ongoing changes, especially a slow-down in this area (Bindschadler and Vornberger, 1998), and it may contribute to a stick-slip velocity pattern observed by Bindschadler and others (2003). A part of Crary Ice Rise was also formed from a raft of cold ice freezing at the bottom about 450 years ago (Bindschadler and others, 1990). Additional features can be found at the WIS shear margins that are related to the super-surge and its aftermath (Whillans and others, 2001). From the temperature profile at borehole J9 downstream of WIS on the Ross Ice Shelf, MacAyeal and Thomas (1979) not only discovered a basal temperature gradient much higher than presently on WIS, but also a basal freeze-on rate of $8 \mathrm{~mm} \mathrm{a}^{-1}$, again pointing inescapably to a major event in the history of the flow of WIS.

\section{SIPLE DOME AND RAYMOND RIDGE}

The summit of Raymond Ridge, Siple Dome was not affected by the super-surge. The temperature profiles are still responding to the last glacial-interglacial temperature changes at the surface 10000 years ago. The basal temperature, now at $-2.54{ }^{\circ} \mathrm{C}$, will reach the melting point in about 6000 years. The basal temperature gradient of $-32.7 \mathrm{~K} \mathrm{~km}^{-1}$ reflects the local geothermal flux of $69 \mathrm{~mW} \mathrm{~m}^{-2}$ (Engelhardt, 2004).

Large areas of present RR, now dormant and probably frozen to the bed, were active during the super-surge period. A prominent scarp to the north delineates the former margin of a whole ice-stream branch, called Siple Ice Stream. The dating of its stagnation also provides a constraint for the super-surge about 500 years ago (Jacobel and others, 2000).

\section{BINDSCHADLER ICE STREAM}

The temperature-depth profile of BIS is almost identical with that of KIS. It belongs to the cold group of basal ice temperatures (Fig. 2). The basal temperature gradient is high at $-61.2 \mathrm{~K} \mathrm{~km}^{-1}$. The base is at the pressure-melting point at $-0.82^{\circ} \mathrm{C}$. A basal debris-laden ice layer about $10 \mathrm{~m}$ thick was encountered on drilling through the basal ice. Figure 6 shows the drilling-hose tension in KIS and BIS, as it varies when the drill is hydraulically mining through the basal debris-laden ice layer, until the drill hits the subglacial till. From borehole video in KIS we know thickness and composition of the debris-laden basal ice. The similarity of the drilling-hose tension plots in both boreholes near the bed suggests that we have similar basal ice layers at both borehole sites. The bed is reached when the water level in the borehole drops from the bottom of the permeable firn layer at $30 \mathrm{~m}$, to a depth of $100 \mathrm{~m}$ below the surface, and simultaneously the tension of the hose increases abruptly. The water-level drop is an indication of the presence of a basal water system. All of the BIS boreholes, which were located no more than $30 \mathrm{~m}$ apart, connected instantly to the basal hydraulic system. The water level dropped to identical depths, indicating a well-developed basal hydraulic system. Abundant basal water is still available at the borehole drill sites. We find that cold ice is still flowing down BIS, and at the same time freeze-on continues at a rate of $7 \mathrm{~mm} \mathrm{a}^{-1}$. These observations fit again into a supersurge scenario in which a great mass of cold ice is swept down the ice-stream path. Because of this cold ice near the base and ongoing freeze-on processes, BIS is very complex in detail, with a number of sticky spots, complicated crevasse patterns, with relict shear margins, more diffuse and much wider than those along WIS, and with a kink in the velocity profile near the ice-streaming onset (Bindschadler and others, 1996, 2000). The Byrd borehole within the catchment area of BIS shows a basal temperature profile comparable to WIS and that of Siple Dome. If normal flow continues, warmer basal ice could eventually replace the cold ice in the same way as is happening on WIS. Since the thermal characteristics of BIS are the same as those of KIS, it is possible that the lower reaches of BIS could shut down by continued freeze-on and loss of water lubrication the same way as KIS did 150 years ago. However, since the amount of water still available or produced in upstream reservoirs is not known, it is hard to predict if and when such a shut-down would actually occur. 


\section{CONCLUSIONS}

The Unicorn paradox shows, side-by-side, high basal temperature gradients at the UC and much lower temperature gradients only a few kilometers away at Whillans Ice Stream. This poses a real challenge to the interpretation of the evolution of the thermal regime of the WAIS. To explain this unusual situation, a major event, like a super-surge, could have happened, which was able to move Kamb Ice Stream ice to the UC across the barrier of the normal course of Whillans Ice Stream. If such a super-surge is the solution to the Unicorn paradox, it then offers also an explanation for many observed features in the Siple Coast ice-stream system. The super-surge activated substantial areas that became stagnant after the surge peaked and subsided about 500 years ago. 'Siple Ice Stream' with a distinct shear margin scarp on the northern flank of Siple Dome is the most prominent example. These stagnant areas are still visible as subtle topographic features at the surface or as buried crevasses detected by radar.

\section{ACKNOWLEDGEMENTS}

Since the fieldwork for this study was completed, the ice streams have been renamed, starting with Whillans Ice Stream in honor of the late I. Whillans who commenced work on Ice Stream B and continued to discover and explain an endless number of features of this peculiar ice stream he was relentlessly dedicated to decipher. Foremost, I thank B. Kamb for his inspiration and constant support. I am very grateful for the good work and the cheerful enthusiasm of our field assistants who helped us in 11 field seasons in Antarctica: N. Humphrey, R. Scherrer, M. Fahnestock, M. Wumkes, J. Chadwick, J. Berkey, H. Aschmann, M. Blume, H. Conway, T. Svitek, J. Zachariasen, D. McKee, L. Allison, T. Melbourne, D. Semmens, M. Sahani, P. Svitek, K. Petersen, P. White, S. Web, M. Jackson, B. Waddington, K. Quinn, K. Svenson, S. Schmidt, E. Miya, K. Echelmeyer, D. Baldwin, S. Wheeler, R. Lohman, B. Pratt, M. Bergman, M. Eaton, J. Hashimoto, C. Weber, E. Hinds, P. Cutler, G. Catania, S. Das, E. Mueller, A. Bucki, S. Colley, A. Blanchard, D. Reusch, H. Schwaiger, B. Farrow, S. Gordon, M. Bachmann, R. Bolsey, G. Gerbi, D. Abrams, S. Vogel, A. Behar, R. Sterr, K. Batten, M. Koppes. The US National Science Foundation Office of Polar Programs funded this work under grant OPP-9615420. In addition, many people of the Antarctic support and logistics groups were essential for this work. I thank two anonymous reviewers for many inspiring suggestions and my editor R. Mulvaney for gentle guidance.

\section{REFERENCES}

Bindschadler, R. and P. Vornberger. 1998. Changes in the West Antarctic ice sheet since 1963 from declassified satellite photography. Science, 279(5351), 689-692.

Bindschadler, R. A., E. P. Roberts and A. Iken. 1990. Age of Crary Ice Rise, Antarctica, determined from temperature-depth profiles. Ann. Glaciol., 14, 13-16.

Bindschadler, R., P. Vornberger, D. Blankenship, T. Scambos and R. Jacobel. 1996. Surface velocity and mass balance of Ice Streams D and E, West Antarctica. J. Glaciol., 42(142), 461-475.

Bindschadler, R., X. Chen and P. Vornberger. 2000. The onset area of Ice Stream D, West Antarctica. J. Glaciol., 46(152), 95-101. (Erratum: 46(153), p. 352.)
Bindschadler, R. A., P. L. Vornberger, M. A. King and L. Padman. 2003. Tidally-driven stick-slip motion in the mouth of Whillans Ice Stream, Antarctica. Ann. Glaciol., 36, 263-272.

Blankenship, D. D., R.E. Bell, S. M. Hodge, J.M. Brozena, J. C. Behrendt and C. A. Finn. 1993. Active volcanism beneath the West Antarctic ice sheet and implications for ice-sheet stability. Nature, 361(6412), 526-529.

Casassa, G. and J. Turner. 1991. Dynamics of the Ross Ice Shelf. [Abstract.] EOS, 72(44), Supplement, 473, 481.

Clarke, T. S., C. Liu, N. E. Lord and C. R. Bentley. 2000. Evidence for a recently abandoned shear margin adjacent to Ice Stream B2, Antarctica, from ice-penetrating radar measurements. J. Geophys. Res., 105(B6), 13,409-13,422.

Conway, H., G. Catania, C. Raymond, T. Scambos, H. Engelhardt and A. Gades. 2002. Switch of flow direction in an Antarctic ice stream. Nature, 419(6906), 465-467.

Engelhardt, H. 2004. Ice temperature and high geothermal flux at Siple Dome, West Antarctica, from borehole measurements. J. Glaciol., 50(169), 251-256.

Engelhardt, H. and B. Kamb. 1993. Vertical temperature profile of Ice Stream B. Antarct. J. U.S., 28(5), Review 1993, 63-66.

Engelhardt, H. and B. Kamb. 1997. Basal hydraulic system of a West Antarctic ice stream: constraints from borehole observations. J. Glaciol., 43(144), 207-230.

Engelhardt, H. and B. Kamb. 1998. Basal sliding of Ice Stream B, West Antarctica. J. Glaciol., 44(147), 223-230.

Fahnestock, M. A., T. A. Scambos, R. A. Bindschadler and G. Kvaran. 2000. A millennium of variable ice flow recorded by the Ross Ice Shelf, Antarctica. J. Glaciol., 46(155), 652-664.

Gow, A. J., H. T. Ueda and D. E. Garfield. 1968. Antarctic ice sheet: preliminary results of first core hole to bedrock. Science, 161(3845), 1011-1013.

Gray, L. and 6 others. 2002. RADARSAT interferometry for Antarctic grounding-zone mapping. Ann. Glaciol., 34, 269-276.

Iken, A., K. Echelmeyer, W. Harrison and M. Funk. 1993. Mechanisms of fast flow in Jakobshavns Isbræ, West Greenland: Part I. Measurements of temperature and water level in deep boreholes. J. Glaciol., 39(131), 15-25.

Jacobel, R. W., T. A. Scambos, N. A. Nereson and C. F. Raymond. 2000. Changes in the margin of Ice Stream C, Antarctica. J. Glaciol., 46(152), 102-110.

Jenssen, D. and U. Radok. 1961. Transient temperature distributions in ice caps and ice shelves. International Association of Scientific Hydrology Publication 55, 112-122.

Kamb, B. 2001. Basal zone of the West Antarctic ice streams and its role in lubrication of their rapid motion. In Alley, R.B. and R. A. Bindschadler, eds. The West Antarctic ice sheet: behavior and environment. Washington, DC, American Geophysical Union, 157-199. (Antarctic Research Series 77.)

Kamb, B. and 7 others. 1985. Glacier surge mechanism: 19821983 surge of Variegated Glacier, Alaska. Science, 227(4686), 469-479.

Lingle, C.S. and T. J. Brown. 1987. A subglacial aquifer bed model and water pressure dependent basal sliding relationship for a West Antarctic ice stream. In Van der Veen, C.J. and J. Oerlemans, eds. Dynamics of the West Antarctic ice sheet. Dordrecht, etc., D. Reidel Publishing Co., 249-285. (Glaciology and Quaternary Geology 4.)

MacAyeal, D. R. and R. H. Thomas. 1979. Ross Ice Shelf temperatures support a history of ice-shelf thickening. Nature, 282(5740), 703-707.

Nereson, N.A. 2000. Elevation of ice-stream margin scars after stagnation. J. Glaciol., 46(152), 111-118.

Nereson, N.A., E. D. Waddington, C. F. Raymond and H. P. Jacobson. 1996. Predicted age-depth scales for Siple Dome and inland WAIS ice cores in West Antarctica. Geophys. Res. Lett., 23(22), 3163-3166.

Nydick, K. R., A. Bidwell, E. Thomas and J. C. Varecamp. 1995. A sea-level rise curve from Guilford, CT. Mar. Geol., 124(1-4), 137-159. 
Radok, U., D. Jenssen and W. Budd. 1970. Steady state temperature profiles in ice sheets. International Association of Hydrological Sciences Publication 86, 151-165.

Retzlaff, R. and C. R. Bentley. 1993. Timing of stagnation of Ice Stream C, West Antarctica, from short-pulse radar studies of buried surface crevasses. J. Glaciol., 39(133), 553-561.

Ritzwoller, M. H., N.M. Shapiro, A. L. Levshin and G.M. Leahy. 2001. The structure of the crust and upper mantle beneath Antarctica and the surrounding oceans. J. Geophys. Res., 106(B12), 30,645-30,670.

Scambos, T.A., N.A. Nereson and M.A. Fahnestock. 1998. Detailed topography of Roosevelt Island and Siple Dome, West Antarctica. Ann. Glaciol., 27, 61-67.

Tulaczyk, S., B. Kamb, R.P. Scherer and H. F. Engelhardt. 1998. Sedimentary processes at the base of the West Antarctic ice stream: constraints from textural and compositional properties of subglacial debris. J. Sediment. Res., 68(3A), 487-496.
Vogel, S. W., S. Tulaczyk and I. R. Joughin. 2003. Distribution of basal melting and freezing beneath tributaries of Ice Stream C: implication for the Holocene decay of the West Antarctic ice sheet. Ann. Glaciol., 36, 273-282.

Wettlaufer, J.S. 1999a. Crystal growth, surface phase transitions and thermomolecular pressure. In Wettlaufer, J.S., J. G. Dash and $\mathrm{N}$. Untersteiner, eds. Ice physics and the natural environment. Berlin, etc., Springer-Verlag, 39-68. (NATO ASI Series I: Global Environmental Change 56, Acquafredda Di Maratea, Italy, 7-19 September 1997.)

Wettlaufer, J.S. 1999b. Impurity effects in the premelting of ice. Phys. Rev. Lett., 82(12), 2516-2519.

Whillans, I. M., C. R. Bentley and C.J. van der Veen. 2001. Ice Streams B and C. In Alley, R.B. and R.A. Bindschadler, eds. The West Antarctic ice sheet: behavior and environment. Washington, DC, American Geophysical Union, 257-281. (Antarctic Research Series 77. 